Dept. of Animal Medicine,

Fac. of Vet. Med., Assiut University, Egypt

\title{
PROTEUS VULGARIS, AN EMERGING FISH PATHOGEN IN EGYPT
}

(With 4 Tables and 5 Figures)

\author{
By \\ SH. M. AHMED and A.A. ELKAMEL \\ (Received at 18/9/2006)

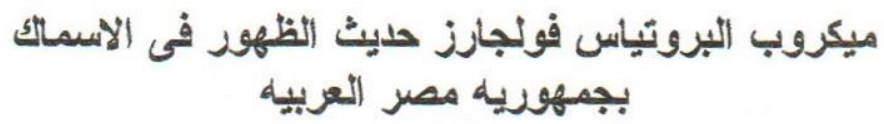 \\ شعبان معد /حمد ، احمد عبد الهادى الكامل
}

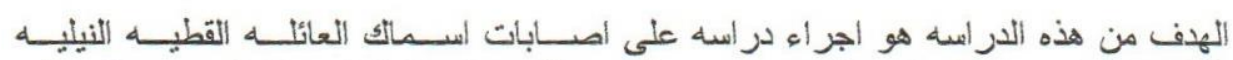

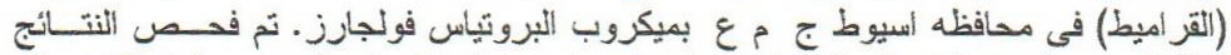

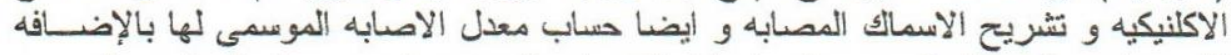

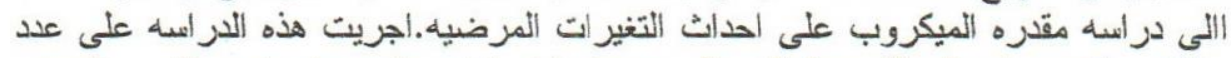

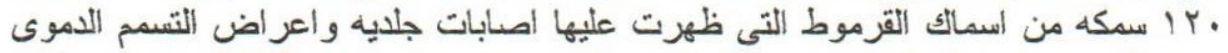

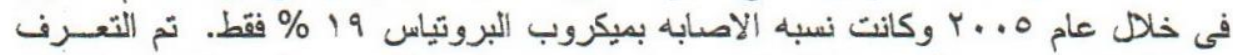

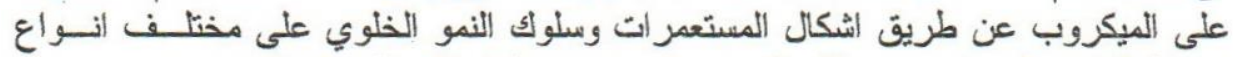

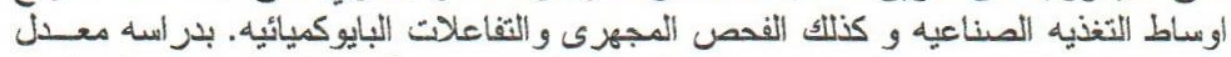

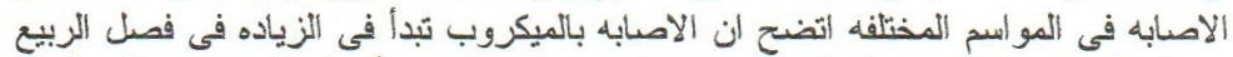

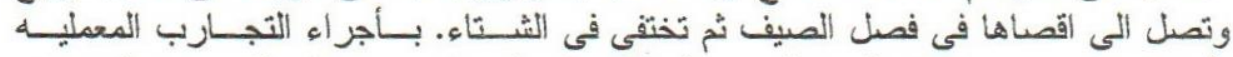

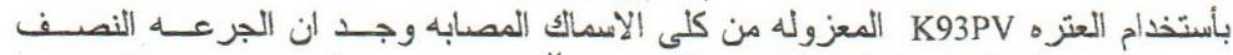

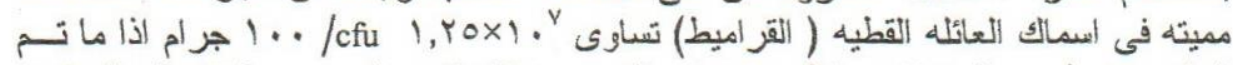

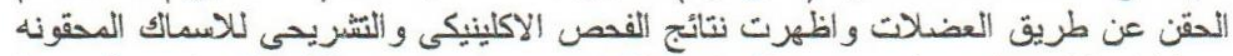

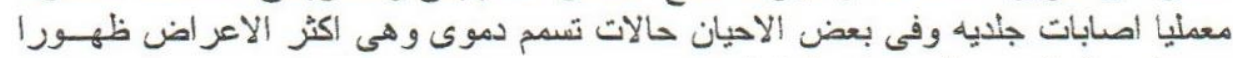

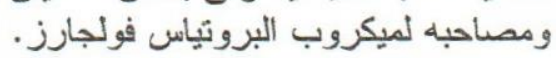

\section{SUMMARY}

The aim of this study was to investigate Proteus vulgaris infections in sharptooth catfish, Clarias gariepinus, in Assiut, Egypt. Clinical and postmortem findings of infected fish and seasonal prevalence of infection were investigated. Pathogenicity of Proteus vulgaris was also assessed. Out of 120 fish showing skin lesions and signs of septicemia examined over year 2005, only 1.58 (\%) fish were infected with Proteus 
vulgaris. Bacteria identification was based on colony morphology and culture behavior on various media, microscopic examination, biochemical tests and carbohydrate fermentation. Strain K93PV isolated from kidneys of infected fish was used throughout this study. Seasonal prevalence of Proteus vulgaris infections increased over spring and reached maximum in summer. Infection was not recorded in winter. Lethal dose $50\left(\mathrm{LD}_{50}\right)$ of Proteus vulgaris in sharptooth catfish was $1.25 \times 10^{7} \mathrm{cfu} / 100 \mathrm{~g}$ fish body weight intramuscularly injected. Clinical and postmortem examination of experimentally infected fish revealed that skin lesions and sometimes generalized septicemia are the predominant signs associated with Proteus vulgaris infection.

Key words: Proteus vulgaris, clarias gariepinus

\section{INTRODUCTION}

Commercial farming of sharptooth catfish, Clarias gariepinus, has significantly increased in Upper Egypt over the past few years. Sharptooth catfish is widely accepted by consumers in Upper Egypt as a relatively cheaper choice of fish protein.

Many communities discharge their waste water into convenient rivers, lakes, or estuaries in spite of the fact that such material contains bacteria capable of causing human diseases. Unfortunately little consideration has been given to the possibility that fish exposed to such contaminated water may develop active infection and diseases. Pathogenic bacteria associated with the digestive tract of man and other mammals have been isolated from many varieties of fish (AbdelRahman et al., 2004; Janssen and Meyers, 1968). Many members of Enterobacteriaceae can establish active infection in fish and persist for several weeks or longer (Lyayman, 1966).

Although Proteus vulgaris is considered mainly a human pathogen, it was reported to produce active infections in fish. Pervious studies reported that $P$. vulgaris causes diseases in several freshwater fish including, ulceration on skin of akame (Muroga, 1979), septicemia in carps (Ramaiah and Manohar, 1987) and mortalities in sharptooth catfish and tilapia (Okaeme, 1989). Furthermore, in a previous study conducted in our lab, $P$. vulgaris has been isolated from tissues of fish grown in ponds contaminated with un-treated chicken manure (AbdelRahman et al., 2004). 
Unfortunately, scarce data present on Proteus vulgaris infections in fish in Egypt. In the present study, prevalence and seasonal prevalence of Proteus vulgaris infections in sharptooth catfish have been investigated over one year. Clinical and postmortem sings and pathogenicity of Proteus vulgaris were also studied.

\section{MATERIALS and METHODS}

\section{Seasonal prevalence and survey:}

A total of 1200 alive sharptooth catfish, Clarias gariepinus, were collected from the small tributaries of El-Ibrahemia canal, Assiut City over a calendar year from January to December 2005 (100 fish/month). Out of the collected samples, 120 fish (10 fish/month) showing signs of infection were selected for thorough examination. The body weight of selected fish ranged from 300 to $350 \mathrm{~g}$ with total length of $30-34 \mathrm{~cm}$.

\section{Clinical and Bacteriological Examination of Samples:}

Fish were examined for any apparent clinical signs or lesions according to Stoskopf (1993). Bacterial sampling were taken from both kidneys, liver and intestinal content on Cefsulodin Iragasan Novobioc (CIN) agar base supplemented with Yersinia selective supply (Biolife, Milno, Italy). Colonies were purified on brain heart infusion (BHI) agar (Biolife)

\section{Bacterial identification:}

Bacterial isolates were identified by colony morphology and cultural behavior on brain heart infusion (BHI) agar, trypticase soya agar (TSA) and salmonella shigella agar (SS agar), microscopic examination (Gram stain and motility test), biochemical tests that include oxidase, indole, Voges Proskauer, methyl red, urease and dnase activities, citrate utilization, triple suger iron reaction (TSI) and carbohydrate fermentation (arabinose, dulcitol, glucose, galactose, lactose, maltose, raffinose, salicin, sorbitol, and sucrose) according to Cowan et al. (1975); Cruickshank et al. (1975), Farmer and Mcwhorter (1984) and Brenner (1984).

\section{Pathogenicity of Proteus vulgaris to Clarias gariepinus}

\section{A- Fish:}

Apparently healthy sharptooth catfish with an average body weight of $100 \pm 5 \mathrm{~g}$ and total length as $19 \pm 1 \mathrm{~cm}$ were obtained from ponds of cultured sharptooth at Minia Governorate. Fish were acclimated to laboratory conditions for 2 weeks according to Ellsaesser and Clem (1986). 


\section{B- Bacterial strains:}

All bacteria strains suspected to be Proteus vulgaris was kept in $\mathrm{BHI}$ broth with $15 \%$ glycerol (El-Gomhurrhia, Cairo, Egypt) at $-20^{\circ} \mathrm{C}$ for further investigations. A bacterial strain isolated from kidney of infected fish and identified as Proteus vulgaris (K93PV) was passed through sharptooth catfish three times and used for determination of $\mathrm{LD}_{50}$ and pathogenicity experiments. Strain K93PV was grown in BHI broth at $28^{\circ} \mathrm{C}$ for 12 hours to mid-log phase (optical density of 1.2 at $600 \mathrm{~nm}$ wave length) to be diluted and used for experimental infection.

\section{C- Bacterial count:}

Using optical density values at wave length of $600 \mathrm{~nm}$ and standard plate count method (Elkamel et al., 2003), colony forming units (cfu) counts in bacterial suspensions were determined. Counts were determined on BHI with $4 \%$ agar to inhibit swarming activities of Proteus vulgaris. Three concentrations of strain K93PV were made in distilled water as $1.25 \times 10^{7}, 2.5 \times 10^{7}$ and $5 \times 10^{7} \mathrm{cfu} / \mathrm{ml}$.

\section{D- Determination of $\mathrm{LD}_{\mathbf{5 0}}$ :}

Sharptooth catfish weighing $100 \pm 5$ grams were divided into nine groups where each group have four fish. All fish of each group were injected either intramuscularly (I/M) or intraperitoneally $(\mathrm{I} / \mathrm{P})$ with $1 \mathrm{ml}$ of one bacterial concentration or distilled water as shown in next table.

\begin{tabular}{|c|c|c|}
\hline Bacterial concentration & Route & No. of injected fish \\
\hline \multirow{2}{*}{$5 \times 10^{7} \mathrm{cfu}$} & $\mathrm{IM}$ & 4 \\
\hline \multirow{2}{*}{$2.5 \times 10^{7} \mathrm{cfu}$} & $\mathrm{IP}$ & 4 \\
\hline \multirow{2}{*}{$1.25 \times 10^{7} \mathrm{cfu}$} & $\mathrm{IM}$ & 4 \\
\hline \multirow{2}{*}{$\begin{array}{c}\text { Control } \\
\text { (distilled water) }\end{array}$} & $\mathrm{IP}$ & 4 \\
\cline { 2 - 3 } & $\mathrm{IM}$ & 4 \\
\cline { 2 - 3 } & $\mathrm{IP}$ & 4 \\
\cline { 2 - 3 } & IM & 4 \\
\hline
\end{tabular}

Mortalities were recorded daily for four days. Moribund fish were bacteriologically examined to isolate the predominant bacteria from the internal organs and site of lesions. By the end of the forth day all fish alive were euthanized and examined. The whole experiment was repeated three times.

\section{E-Experimental infection:}

Sharptooth catfish weighing $100 \pm 5$ grams were divided into three groups where each group have five fish. One $\mathrm{ml}$ of a bacterial suspension $1 \mathrm{X} 10^{7} \mathrm{cfu} / \mathrm{ml}$ was $\mathrm{I} / \mathrm{M}$ injected in all fish of one group. Two 
groups (injected and non-injected) acted as

$I / M$ injected with $1 \mathrm{ml}$ of distilled water as control, where a group was

Alive and Clinical signs and mortalities wer the other one remained un

the predominant dead fish were bacteriologically daily for 10 days.

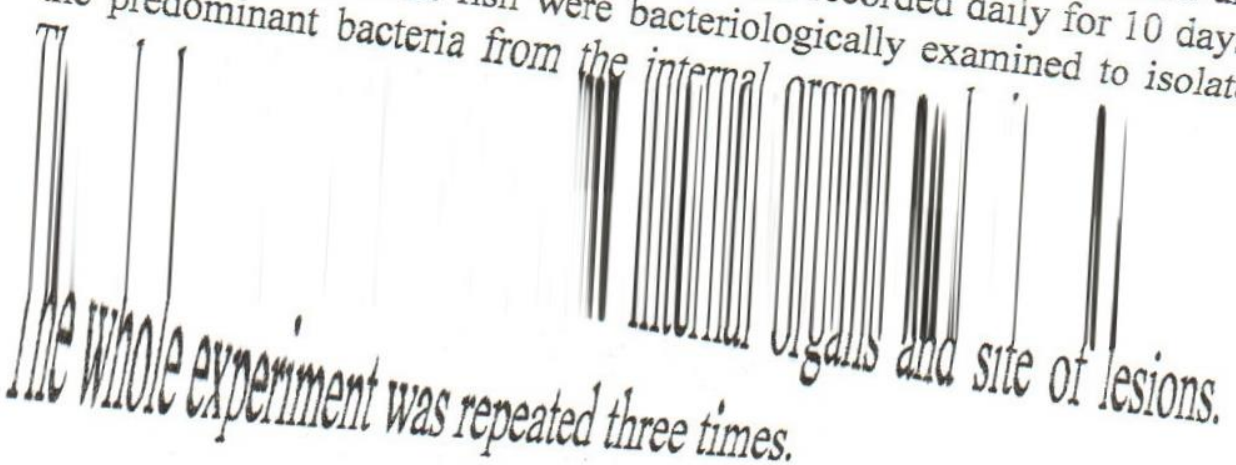

\section{RESULTS}

Clinical Examination showing signs of septicemia and/or skin esions were selected atter cariepinus. Fish showed several ulcerative sharptooth catfish, Clarias o noticed. Also, petechial haemorrhages lesions on body surface were parts of the body particularly in mouth were widely spread in mant the base of fins with fin rot. There were region, body surface and at opacity either in one or both eyes in some of exophthalmia and corneal opas congested in some cases, whe liver surface the examined fish. Liver haemorrhages were observed on the of liver. Gall other cases. Pecal haemorrhages were also observed with bile. Spleen and kidney were bladder was enlarged and filled will inflamed and blood vessels were congested. Bacterial examination resulted 120 fish showing clinical signs of liver, kidney and intestition was done on $\mathrm{CIN}$ agar. Based strains were infection. Primary is characters and swarming actl on CIN agar with red and morpholog Proteus sp. Colonies grew On SS agar colonies were center that is surrounded by clear zone central spot. BHI and TSA agar whitish or colorless with or without dark colonies that could be inhibited when agar showed highly swarming colonies dia. Colonies on BHI with $4 \%$ agar concentration reaches $4 \%$ ind transparent.

media were thin, colentification Bacteriologit of 170 strains isolated from $(1235 \%)$ were suspected to be $P$.
Out Out of 17 mined, 21 strains ( $12.35 \%$ ) weters and biochemical selected fish exding to morphological chected $P$. vulgaris strains were selected
vulgaris according to morph, all suspected $P$. vulgaris
identification. Microscopically motile, Gram-negative rods ton 
filaments. Biochemical characters of the suspected 21 strains strongly suggest that those strains are $P$. vulgaris (Table 1).

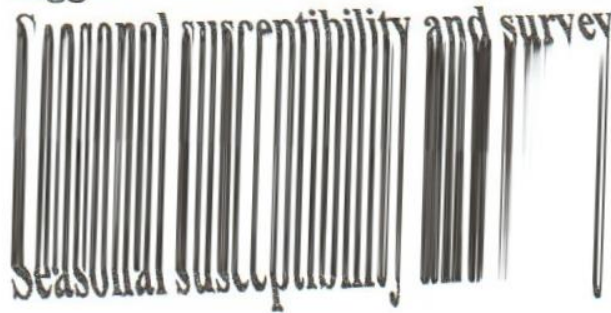

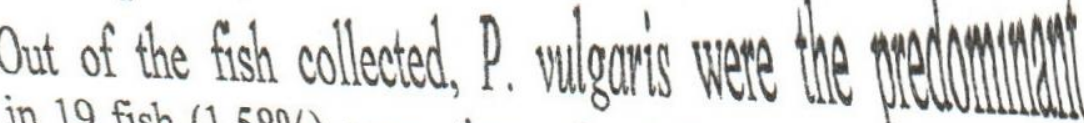
$P$. vulgaris infect lom the same fis Proteus vulgaris of the fish catfish when in strain K93PV died. On the othed with a dose of . Within 96 hours bo pathogenic to Intere were highly lethal $2.5 \times 10^{7}$ and $1.25 \times 10^{7} \mathrm{cfu}$ hours post infection half $\mathrm{cfu} / 100 \mathrm{~g}$ fish $\mathrm{I} / \mathrm{P}$ injection of fish almost all fish $\mathrm{cfu} / 00 \mathrm{~g}$ fish body weight and. P. vulgaris weight) did not even with within the first weight isolated organs of re-isolated in pur to death highest dose 4 days. Experimom internal all $\mathrm{L} M$ injected fire culture from any fish but $\left(5 \times 10^{7}\right.$ Exptal infection ans of all I/P fish. Althour from site of in only easily caperimentally increased reactions. The most promi mucus whe sluggish in and paleness of injection surrounding of the skin. Ulig. 1). It begin the form of surface is the cesses may devel, white pale with a thin with severe local ise local underlying may slough and tissues becor was then dish hyperemicmia generalized tissues become creating well de very friable body surface particemia were exposed (Fig. 3 ). Post-mortem particularly abserved. 3). In some ulcers with in severely inflamination appeared at Petechial hame cases, sign the petechial antlamed and frowed that tissue of fin arrhages on of (Fig. 4). Gall focal haemoriable. Liver tissues at site and on the the were congested bladder was enge on the was congested of injection are blood vesseIs of and enlarged. enlarged and disten and edge addition to fish died at the fifth and larger in size was observed internal organ Kidneys with day post injection. with rounded (Fig.4). Spleen and 
Table 1: Characters of 21 strains that are suspected to be Proteus vulgaris.

\begin{tabular}{|c|c|c|}
\hline \multicolumn{2}{|c|}{ Test } & $P$. vulgaris suspected strains \\
\hline \multicolumn{2}{|c|}{ Gram stain } & - \\
\hline \multicolumn{2}{|l|}{ Motility } & $21 / 0$ \\
\hline \multicolumn{2}{|l|}{ Oxidase } & $0 / 21$ \\
\hline \multicolumn{2}{|c|}{ Vogus Proskauer } & $0 / 21$ \\
\hline \multicolumn{2}{|c|}{ Indole } & $21 / 0$ \\
\hline \multicolumn{2}{|c|}{ Methyl red } & $21 / 0$ \\
\hline \multirow{3}{*}{ TSI } & $\mathrm{H}_{2} \mathrm{~S}$ & $21 / 0$ \\
\hline & Gas & $21 / 0$ \\
\hline & $\mathrm{K} / \mathrm{A}$ & $2 / 19$ \\
\hline \multicolumn{2}{|l|}{ Urease } & $21 / 0$ \\
\hline \multicolumn{2}{|c|}{ Simmon's citrate } & $2 / 19$ \\
\hline \multicolumn{2}{|c|}{ DNAse } & $0 / 21$ \\
\hline \multicolumn{2}{|l|}{ Arbanios } & - \\
\hline \multicolumn{2}{|l|}{ Dulcitol } & - \\
\hline \multicolumn{2}{|l|}{ Glucose } & + \\
\hline \multicolumn{2}{|l|}{ Galactose } & - \\
\hline \multicolumn{2}{|l|}{ Lactose } & - \\
\hline \multicolumn{2}{|l|}{ Maltose } & - \\
\hline \multicolumn{2}{|l|}{ Rafinose } & - \\
\hline \multicolumn{2}{|l|}{ Salicin } & + \\
\hline \multicolumn{2}{|l|}{ Sorbitol } & - \\
\hline \multicolumn{2}{|l|}{ Sucrose } & - \\
\hline
\end{tabular}

Table 2: Seasonal susceptibility of Clarias gariepinus to Proteus vulgaris infection.

\begin{tabular}{|c|c|c|c|}
\hline Season & $\begin{array}{c}\text { No. of fish } \\
\text { collected }\end{array}$ & No. of fish infected & Percent of infection \\
\hline Winter & 300 & 0 & 0 \\
\hline Spring & 300 & 7 & 2.33 \\
\hline Summer & 300 & 10 & 3.33 \\
\hline Autumn & 300 & 2 & 0.33 \\
\hline
\end{tabular}

Table 3: Organ susceptibility of Clarias gariepinus to Proteus vulgaris infection.

\begin{tabular}{|c|c|c|c|c|}
\hline \multirow{2}{*}{ Organ } & \multicolumn{2}{|c|}{ Infected fish $(\mathrm{n}=19)$} & \multicolumn{2}{c|}{ Isolated strains $(\mathrm{n}=21)$} \\
\cline { 2 - 5 } & No. & $\%$ & No. & $\%$ \\
\hline Liver & 4 & 21.1 & 5 & 23.81 \\
\hline Kidney & 7 & 36.8 & 7 & 33.33 \\
\hline Intestine & 8 & 42.1 & 9 & 42.86 \\
\hline
\end{tabular}


Table 4: Determination of $\mathrm{LD}_{50}$. Data are from one of three experiments.

\begin{tabular}{|c|c|c|c|c|c|c|}
\hline \multirow{2}{*}{ Dose } & \multirow{2}{*}{ Injection } & \multicolumn{4}{|c|}{ No. of fish died post infection } & \multirow{2}{*}{$\begin{array}{c}\text { No. of fish } \\
\text { survived }\end{array}$} \\
\hline & & Day 1 & Day 2 & Day 3 & Day 4 & \\
\hline \multirow{2}{*}{$5 \times 10^{7}$ cfu } & IM & 2 & 2 & - & - & 0 \\
\hline & IP & 0 & 0 & I & 0 & 3 \\
\hline \multirow{2}{*}{$2.5 \times 10^{7} \mathrm{cfu}$} & IM & 1 & 2 & 0 & 0 & 1 \\
\hline & IP & 0 & 0 & 0 & 0 & 4 \\
\hline \multirow{2}{*}{$1.25 \times 10^{7} \mathrm{cfu}$} & IM & 0 & 1 & 1 & 0 & 2 \\
\hline & IP & 0 & 0 & 0 & 0 & 4 \\
\hline \multirow{3}{*}{$\begin{array}{c}\text { Control } \\
\text { (distilled } \\
\text { water) }\end{array}$} & $\mathrm{IM}$ & 0 & 0 & 0 & 0 & 4 \\
\hline & IP & 0 & 0 & 0 & 0 & 4 \\
\hline & Un-injected & 0 & 0 & 0 & 0 & 4 \\
\hline
\end{tabular}

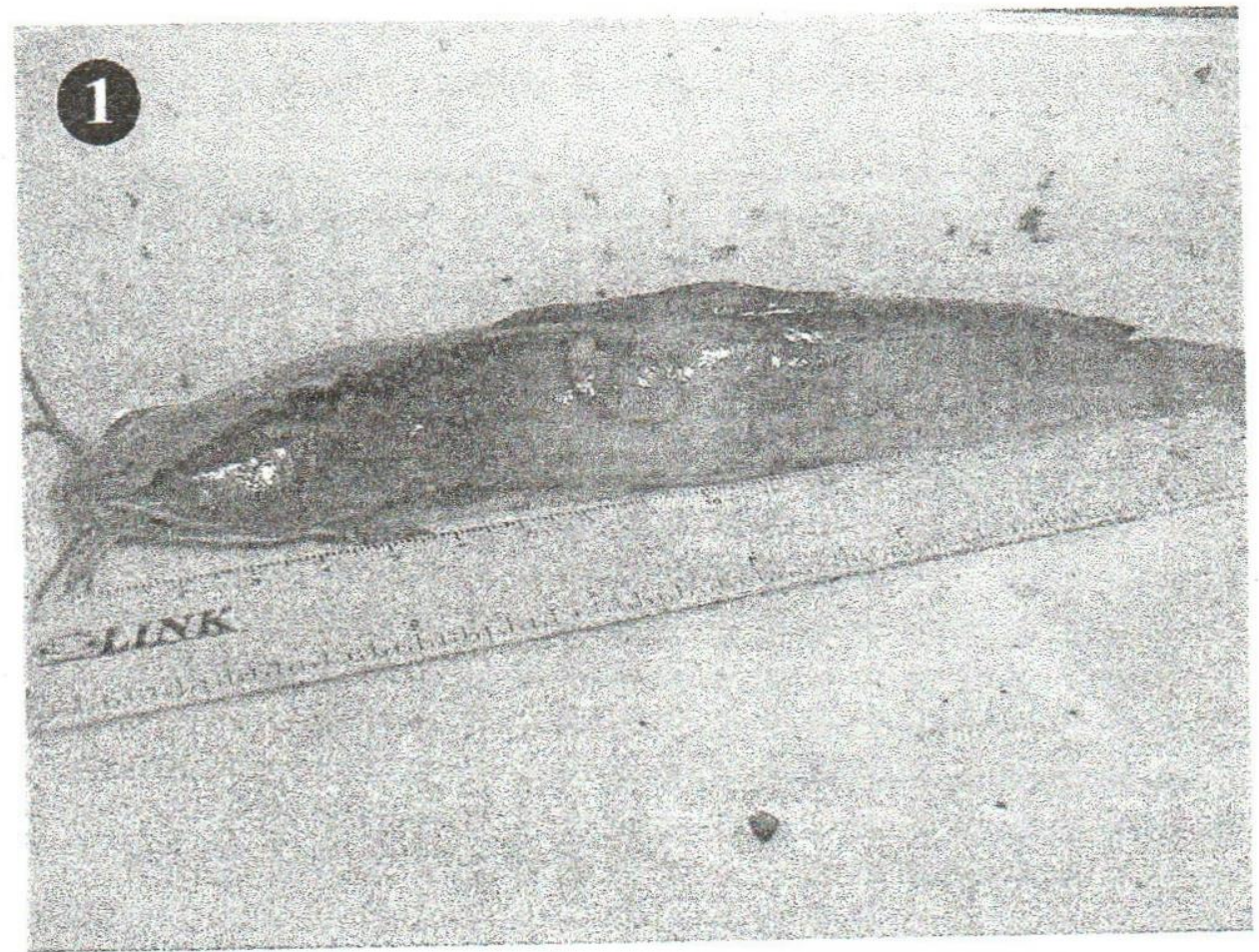

Fig. 1: Sharptooth catfish, Clarias gariepinus, 24 hours post intramuscular injection with Proteus vulgaris $\left(1 \times 10^{7} \mathrm{cfu} / 100 \mathrm{~g}\right.$ body weight) showing severe local reactions at site of injection. 


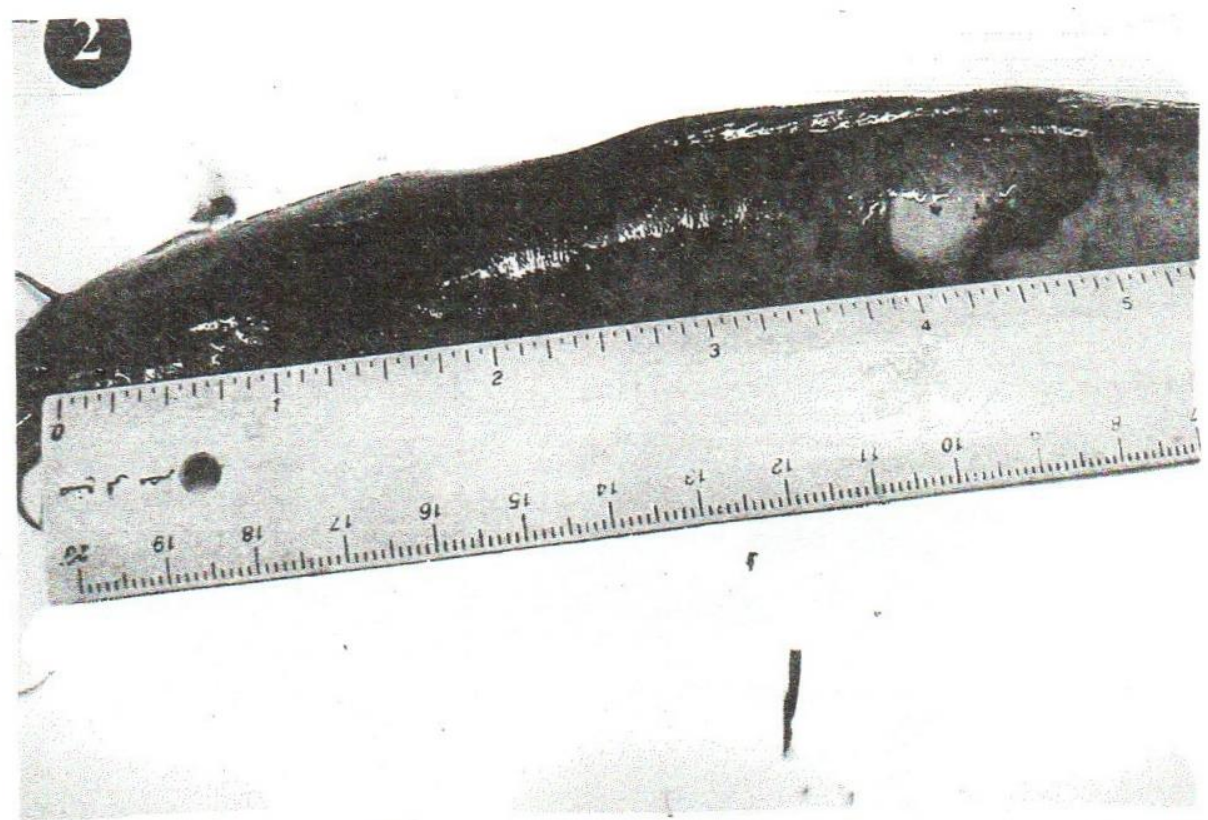

Fig. 2: Sharptooth catfish, Clarias gariepinus, 48 hours post intramuscular injection with Proteus vulgaris $\left(1 \mathrm{X} 10^{7} \mathrm{cfu} / 100 \mathrm{~g}\right.$ body weight) showing skin ulcers.
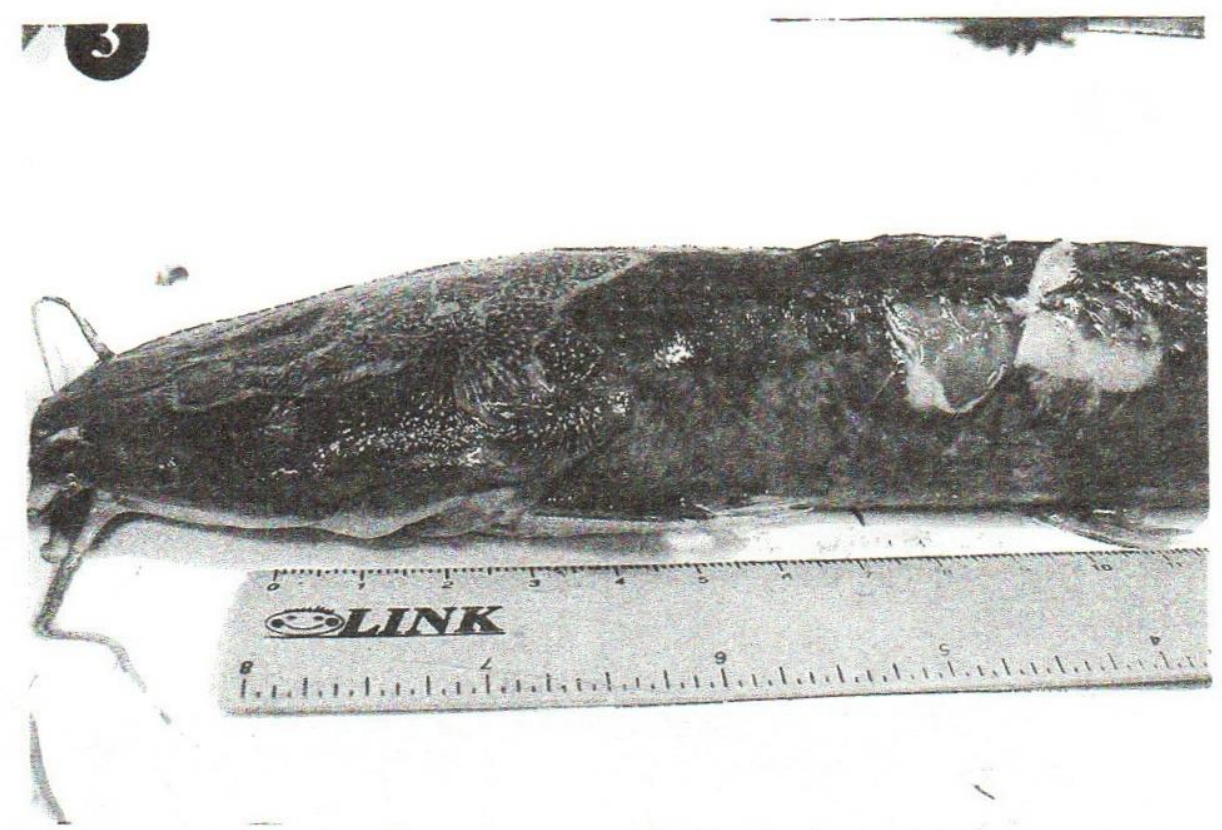

Fig. 3: Sharptooth catfish, Clarias gariepinus, 72 hours post intramuscular injection with Proteus vulgaris ( $1 \mathrm{X} 10^{7} \mathrm{cfu} / 10.0 \mathrm{~g}$ body weight) showing open ulcers and sloughing of dead tissues. 


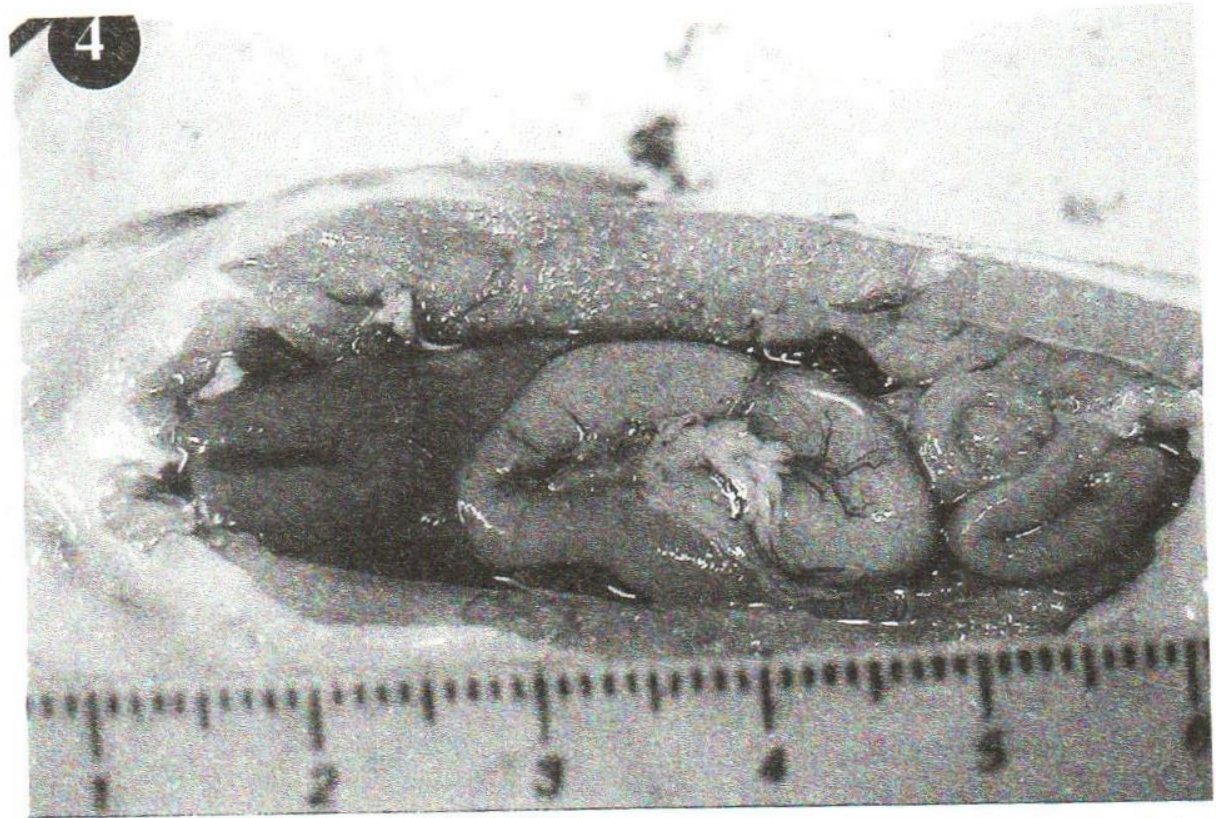

Fig. 4: Sharptooth catfish, Clarias gariepinus, 72 hours post intramuscular injection with Proteus vulgaris (1X107 cfu/100g body weight) showing congestion of liver and intestine.

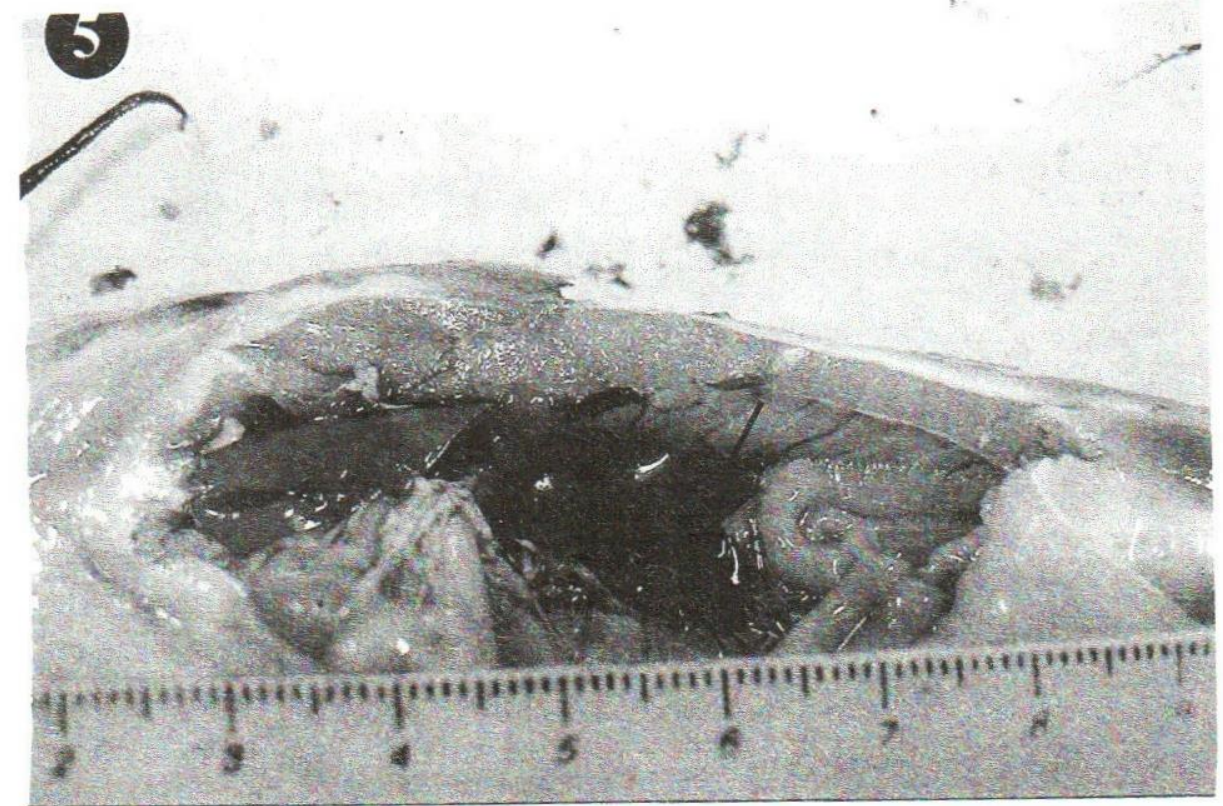

Fig. 5: Sharptooth catfish, Clarias gariepinus, 72 hours post intramuscular injection with Proteus vulgaris $\left(1 \mathrm{X} 10^{7} \mathrm{cfu} / 100 \mathrm{~g}\right.$ body weight) showing enlarged spleen with rounded edges (arrow). 


\section{DISCUSSION}

Present study revealed that Proteus vulgaris infection of sharptooth catfish, C. gariepinus, is an emerging disease in Egypt. A pervious study that reported the isolation of Proteus spp. from fish was the driving force behind conducting this investigation (Abdel-Rahman et al., 2004). Those findings lead to a large-scale study to investigate the seasonal prevalence, clinical signs and post mortem lesions of $P$. vulgaris infection in sharptooth catfish. Also, $\mathrm{LD}_{50}$ of $P$. vulgaris was determined.

Most of studies that investigated $P$. vulgaris contamination of fish focused on water quality issues or the role of fish in transmitting such pathogen to human and food poisoning (Okpokwasili and Alapiki, 1990; and Youssef et al., 1992), but overlooked the impact or the risk on fish health itself. Some studies previously, however, described $P$. vulgaris infections in fish, and this study is the first to characterize infections of sharptooth catfish in Egypt.

Thomas et al. (1983) have shown that fish grown in ponds containing waste water accumulate Enterobacteriaceae, including Proteus spp., that penetrate into the muscle tissues of fish. Okaeme (1989) reported that $P$. vulgaris among other bacteria were the main cause of mortalities in hatcheries and outdoor ponds of tilapias and sharptooth catfish. P. vulgaris was also isolated from external ulceration of freshwater Channa punctatus (Mandal et al., 2002). Based on serological evidences, a study has concluded that fish exposed to enteric bacteria that are mainly human pathogens may become actively infected with such pathogens (Janssen and Meyers, 1968).

Clinical examination of infected fish showed that skin lesions and general septicemia are the main signs of suspected naturally infected fish. Septicemia may be due to generalized infection where liver and most internal organs become congested. Spleen and gall bladder become also enlarged. Badran et al. (1994) concluded that clinical signs of fish infected with human Enterobacteriaceae, which are not considered classical fish pathogens bacteria, are not quite different than those of classical fish pathogens. Okaeme (1989) stated that signs of fish infected with $P$. vulgaris and other bacteria are ulceration and necrotic lesions of skin, abdominal dropsy and haemorrhagic septicemia. Furthermore, Skin ulceration and lesions were reported in an infection with $P$. vulgaris and other bacteria that were complicated with a parasitic copepod in akame (Muroga, 1979). 
Bacteriological sampling of selected fish was done from internal organs but not from surface or skin of fish. Isolation of $P$. vulgaris from internal organs suggests a condition of generalized infection rather than a surface contamination. Accurate identification of bacterial strains suspected to be $P$. vulgaris was done through investigating 20 morphological, growth characters and biochemical characters. Strain $\mathrm{K} 93 \mathrm{PV}$ isolated in June 2005 from kidneys of a fish showing signs of septicemia and skin lesion was identified as $P$. vulgaris and used thorough out this study for determination of $\mathrm{LD}_{50}$ and pathogenicity study. Primary isolation was done on CIN agar which is a selective media for Yersinia.

Prevalence of infection was $1.58 \%$ of all fish collected over one year. The prevalence of $P$. vulgaris infection increased in spring and summer, while decreased in autumn and disappeared in winter. Results suggest that water temperature has a great effect on prevalence of infection. Prevalence of infection is highest when the water temperature is highest in summer when it matches the optimum temperature for growth of $P$. vulgaris. Although water temperature in autumn is more suitable for $P$. vulgaris than that in spring, the infections prevalence was higher in spring. These results may be due to the fact that the immune system of fish in spring would be still recovering from the cold winter and not fully protective against infections. On the other hand, organ susceptibility study showed that $P$. vulgaris is mainly isolated from the fish intestine $(42.1 \%)$. These findings were expected as $P$. vulgaris is a member of family Enterobacteriaceae that inhabit intestinal tract of vertebrates. Kidneys come second in organ susceptibility where $P$. vulgaris was isolated from $7(36.8 \%)$ cases. Isolation of from liver occurred in $4(21.1 \%)$ cases.

Results revealed that $1.25 \times 10^{7} \mathrm{cfu} / 100 \mathrm{~g}$ fish body weight is the $\mathrm{LD}_{50}$ dose when $\mathrm{I} / \mathrm{M}$ injected. The two higher doses proved to be highly lethal to fish when $\mathrm{I} / \mathrm{M}$ injected. An earlier study concluded that $\mathrm{LD}_{50}$ of $P$. vulgaris in carp fingerlings and yearlings was $0.48 \times 10^{5} \mathrm{cfu} / \mathrm{fish}$ (Ramaiah and Manohar, 1988). The differences in $\mathrm{LD}_{50}$ doses from previous study may be due to species, lifestyle, or age differences. Sharptooth catfish may be more naturally resistant to $P$. vulgaris than carps. Because of its lifestyle, sharptooth catfish may be exposed to bacterial agents more than other species of fish which might results in developing of some level of resistant to bacterial infections. In addition, carps used in such study were younger than sharptooth catfish used in
present study. 
Surprisingly, I/P injection of $P$. vulgaris in the same doses used with $\mathrm{I} / \mathrm{M}$ injection did not lead to killing of injected fish but one. Only one fish died after I/P injection with the highest dose of $P$. vulgaris that could be either due to stress or overwhelming of the immune system with bacteria. Although $P$. vulgaris could be isolated from internal organs of fish up to four days post $\mathrm{I} / \mathrm{P}$ injection, no major external clinical signs were obvious. Those results suggest that fish I/P injected with $P$. vulgaris can either overcome infection or completely recover.

Results of present study could give clues about route of natural infection with $P$. vulgaris in sharptooth catfish. Skin injuries would be a major route of infection where bacteria penetrate though compromised skin giving a strong local reaction. Fish live in small tributaries of ElIbrahimiah canal are subject to sewage and waste water. Bacteria go through skin might remain in the underlying tissues and multiply to overwhelm the immune system causing a generalized infection at terminal stages. Alternatively, $P$. vulgaris, a normal inhabitant of fish intestine, might seize stress conditions that fish face to cause septicemia and generalized infection. In both cases, $P$. vulgaris may require stress conditions to induce an active infection in fish. Although, those bacteria are not considered classical fish pathogens, yet adverse environmental conditions and poor water quality render fish more susceptible to infection with those bacteria (Badran et al., 1994).

Further investigations should be done to study the epidemiology of $P$. vulgaris in fish.

\section{ACKNOWLEDGMENT}

We would like to thank Dr. Mohamed S. Baddary, professor of microbiology and immunology, Faculty of Medicine, Assiut University for his input and help in identifying of the bacterial strains.

\section{REFERENCES}

Abdel-Rahman A.A.; Elkamel, A.A.; Neveen, A.H. and Ahmed, Sh. M., (2004): Hazards Associated With The Use of Chicken Manure in Fertilization of Fish Ponds. Assiut Veterinary Medical Journal, 50 (100): 53-65

Elkamel, A.A. and Thune, R.L. (2003): Invasion and Replication of Photobacterium damselae subspecies piscicida in Fish Cell Lines. Journal of Aquatic Animal Health, 15: 167-174 
Badran, A.F.; Eissa, I.A.M. and El-Attar, A.A. (1994): Some Microbiological Problems in Freshwater Fish Farms with Domestic Wastewater Pollution. J. Egypt. Vet. Med. Ass. Vol. 54 No. 4 , pp. 303-311

Brenner, D.J. (1984): Family Enterobacteriaceae, in: kairg, N. R. and Holt, J. G. eds. Bergey's manual of systematic bacteriology, Vol. I: Williams and Baltimore. U.S.A. pp. 409-516.

Cowan, S.T.; Holt, J.G.; Liston, J.G.; Liston, J.; Murray, R.G.E.; Niven, C.F.; Ravin, C.F.; Ravin, A.W. and Stanier, R.W. (1975): In Buchanen, R. E. and Gibbons, N. E., eds. Bergey's manual of determinative bacteriology. $8^{\text {th }}$ Ed. Williams and Wikins Co., Baltimore, MD. pp. 1-268.

Cruickshank, K.R.; Duguid, J.P.; Marmion, B.P. and Swain, R.H. (1975): Tests for identification of bacteria in: Medical microbiology $12^{\text {th }}$ Ed. Vol. II. Churchill Livingstone. Edinburgl, London and New York. pp. 170-189.

Ellsaesser, C.F. and Clem, L.W. (1986): Hematological and immunological changes in channel catfish by handing and transport. Journal of Fish Biology. 28: 511-521.

Farmer, J.J. III and McWhorter, A.C. (1984): Genus X, Edwardisella Ewing and McWhorter (1965). In: Kairg, N. R. and Holt, J. G. (eds) Bergey's namual of systematic bacteriology, Vol. I. Williams and Baltimore. U.S.A. pp. 486-491.

Farmer, J.J. III. Enterobacteriaceae: Introduction and identification. 1995: In Murray, PR., Baron, EJ., Pfaller, MA, Tenover, CF. Yolken, RH. (eds). Manual of clinical microbiology. $6^{\text {th }}$ ed. ASM Press, Washington D.C.P. 438-464.

Finegold, S.M. and Martin, W.J. (1982): Bailey and scott's diagnostic microbiology. $6^{\text {th }}$ Ed. The C.V. Mosby Co., St. Lowis, Tornoto, London.

Janssen, Warner A. and Meyer, Caldwell D. (1968): Fish: Serologic evidence of infection with human pathogens. Science 159 (3814), pp. 547-548.

Lyayman, E.M. (1966): Textbook on the Diseases of Fish. $3^{\text {rd }}$ edition, pp. 115-122. Izd, Vysshays Shkola, Moscow. Wallingford, Oxon, UK.

Mandal, S.; Mandal, M.; Pal, N.K.; Halder, P.K. and Basu, P.S. (2002): $\mathrm{R}$-factor in Proteus vulgaris from ulcerative disease of fish, Channa punctatus. Indian J Exp Biol. 40 (5), pp. 614-616 
Muroga, K. (1979): Ulcer disease of Akame mugilidae in the estuary of the river Ashida Japan. Fish Pathology. 13 (3): 163-168.

Okaeme, A.N. (1989): Bacteria associated with mortality in tilapias Heterobranchus bidorsalis and Clarias lazera in indoor hatcheries and outdoor ponds. Journal of Aquaculture in the Tropiccs. 4 (2), pp. 143-146.

Okpokwasili, G.C. and Alapiki, A.M. (1990): Bacterial flora associated with a nigerian freshwater fish culture. Journal of Aquaculture in the Tropiccs. 5 (1), pp. 87-90.

Ramaiah, N. and Manohar, L. (1988): Indian Fisheries Forum, Mangalore (India). Joseph, M. Editor. ISBN 8183340005

Stokes, J.E. and Ridgeway, G.L. (1980): Clinical bacteriology, chapter 7, Edwardsiella publishers, 5 the edition.

Stoskopf, M.K. (1993): Fish Medicine. W. B. Saunders Co. Philadelphia, Pennsylvania, 19106, USA.

Thomas, W.H.; Charles, P.G.; Scott, II and Mike, F. (1983): Bacteriological, Virological and chemical evazlution of a waste water-aquaculture system. Water Res. Vol.17, No12 pp.17491755.

Youssef, H.; El-Timawy, A.K. and Ahmed, S. (1992): Journal of Food Protection. Vol. 55(9) pp. 739-740. 
